\title{
A contribuição da Teologia Feminista Latino-Americana para a Promoção do Diálogo Inter-Religioso
}

\author{
The contribution of Latin American Feminist Theology for \\ the Promotion of Interreligious Dialogue
}

\author{
Edla Eggert \\ Luísa de Lucas
}

\section{Resumo}

Este artigo tem a finalidade de analisar os fatores que contribuíram para a emergência da Teologia Feminista na América Latina, as fases dessa produção e as estratégias que possibilitaram a sua consolidação e o reconhecimento no campo acadêmico de hegemonia masculina, para compreender o status dessa Teologia e a sua importância no campo do saber teológico e do diálogo inter-religioso. A Teologia Feminista ganha vida através das experiências cotidianas de mulheres e homens por meio de fatores socioculturais, étnico/raciais, entre outros. Com raízes na Teologia da Libertação, a teologia feminista latino-americana surge ligada ao Primeiro Mundo, mas depois segue com suas características próprias a partir da singularidade do contexto latino-americano. Através da atuação de tantas mulheres, seja pelo estudo da Bíblia, nas comunidades e em suas igrejas, elas ocupam seu espaço, encontram novos desafios da nossa atualidade, entre eles, a contribuição e a reflexão da Teologia Feminista diante do pluralismo religioso. A teologia feminista pode contribuir com essa revisão do lugar da religião no projeto de libertação e promover uma teologia de integridade, paz e dialogicidade num Continente tão multicultural, de diferentes etnias, raças e religiosidades.

Palavras-chaves: Mulher. Teologia Feminista. Gênero. Teologia da Libertação. História. Diálogo Inter-Religioso. 


\begin{abstract}
The purpose of this article is to analyze the elements that have contributed to the development of feminist theology in Latin America, the stages of its emergence and the strategies that favored its consolidation and recognition in this academic field long-dominated by a masculinist mentality, and to understand the status of this theology and its importance in theological knowledge and interreligious dialogue. Feminist theology takes flesh through everyday experiences of women and men as a consequence of sociocultural, ethnic, racial, and other factors. Rooted in Liberation Theology, Latin American feminist theology emerges as connected to the First World, but then developing with its own characteristics due to the singularity of the Latin American context. Through the active engagement of so many women, either by studyng the Bible or in their communities and churches, women occupying your space, advancing to deal with new challenges of our times, for example, the contribution on reflecting about Feminist Theology in the face of religious pluralism. Feminist theology can contribute for the understanding of the role of religion in the project of liberation, and to promoting a theology of integrity, peace and dialogue in a continent that is so multicultural, with different ethnicities, races and religions.
\end{abstract}

Keywords: Women. Feminist Theology. Gender. Liberation Theology. History. Interreligious dialogue.

\title{
Introdução
}

O debate sobre o pluralismo religioso se torna cada vez mais importante na América Latina devido às diferenças multiculturais e multirreligiosas presentes no Continente. Considerando a realidade marcada pela intolerância religiosa, a desigualdade econômica, aliada a interesses políticos, e o crescente índice de violência e morte de muitos inocentes, tudo isso, agrava ainda mais a situação social, especialmente das pessoas empobrecidas. Com a Teologia da Libertação a partir de 1960, quem era oprimida e marginalizada passou a ser mais e mais visibilizada e aprendeu junto com as pastorais a se posicionar. Os debates sobre classe social e raça/etnia em grande medida foram considerados, mas os debates sobre gênero foram, em grande medida, deixados de lado. É fundamental mostrar o grande abismo de diferenças que existe na condição de vida entre os homens e as mulheres empobrecidas, e é esse o objetivo desse artigo. 
De acordo com Jonh Hick, ${ }^{1}$ o Cristianismo pode dar respostas plausíveis sobre os problemas sociais que afetam a todas as pessoas, crentes e não-crentes, a partir do significado de Jesus Cristo hoje e da doutrina de sua encarnação. Porém, as teólogas feministas têm ido mais além, não só pela análise do tema da Cristologia, mas por procurarem aprofundar temáticas como o Monoteísmo e as metáforas patriarcais que construíram e impuseram uma imagem de Deus. Para transformar as estruturas injustas e a própria teologia que provocaram a miséria, a violência e a exclusão, nos parece significativo debater estas questões para que a haja a tão sonhada transformação e a vivência aqui e agora do Reino entre nós.

$\mathrm{Na}$ América Latina, as mulheres têm conduzido debates mais ao redor dos dogmas androcêntricos e sexistas, que as excluem das instâncias de decisão e do poder, nas igrejas do que propriamente nas diferenças entre as religiões. Constata-se que esses dogmas marginalizam não só as mulheres, mas os próprios homens de diferentes raças e culturas, discriminadas socialmente em nome de um "Cristo branco, de traços europeus". ${ }^{2}$

A Teologia Feminista na América Latina surge conectada com a Teologia Feminista do hemisfério norte, eurocêntrico, mas segue com as características específicas da singularidade do contexto sociocultural latinoamericano e suas etnias indígenas e afro-descendentes junto com os brancos vindos do além mar. Entendemos que as mulheres latino-americanas e caribenhas possuem diferentes realidades histórias, culturais, sociais e étnicas. O lugar social é fundamental para entender a vida e a experiência das mulheres. ${ }^{3}$ Esse debate se intensifica nos anos 1970 e 1980 e, aos poucos, foi se consolidando e se abrindo, também para a abordagem dos estudos de gênero. A Teologia da Libertação, a partir da perspectiva da mulher latino-americana, elabora, desde sua própria realidade e da consciência das mulheres oprimidas, aquilo que a teóloga mexicana Maria Aquino propõe pensar:

Com o exercício da reflexão teológica trata-se de perguntar à Escritura, ao contexto histórico que lhe deu origem, à tradição de nossos povos ancestrais, à tradição e aos ensinamentos da Igreja, à teologia em geral, ao povo de Deus e à própria realidade histórica atual, sobre a consistência da mulher como sujeito de pleno direito na igreja e na sociedade. Dito de forma sucinta, a teologia feminista latino-americana é uma reflexão crítica, emanada da fé, sobre a experiência de Deus, vivida na prática libertadora das mulheres, informada pela divina página contida nas

\footnotetext{
${ }^{1}$ HICK, J., A metáfora do Deus encarnado, p. 144.

${ }^{2}$ AQUINO, M. P., A Teologia, a Igreja e a Mulher na América Latina, p. 39.

${ }^{3}$ AQUINO, M. P., A Teologia, a Igreja e a Mulher na América Latina, p. 55.
} 
tradições libertadoras da Escritura, pela tradição vívida da Igreja e pela realidade atual. ${ }^{4}$

Nesse sentido, a Teologia Feminista começa como um movimento que promove espaço para novas experiências de vida, provocando mudanças na linguagem religiosa e na prática de algumas Igrejas cristãs. Ela cria uma primeira ruptura básica com o exclusivismo patriarcal e introduz a primeira diferença fundamental e origem de todas as demais diferenças, a diversidade humana, compartilhando de teorias, lutas e reinvindicações de mulheres, nos diversos movimentos libertadores, na promoção da integridade humana para as mulheres, em seus vínculos familiares e sociais. Um exemplo disso é o método da desconstrução do vocabulário, dos pensamentos e valores patriarcais, de acordo com a teóloga Luiza Tomita:

Este método tem sido muito importante para mostrar que a maioria dos ensinamentos cristãos foram baseados em uma perspectiva patriarcal, em que os homens têm o poder e às mulheres restava ocupar o segundo ou o terceiro lugar, nas igrejas e no lar. Assim, foi imposta a ideia da masculinidade de Deus, subjacente aos ensinamentos doutrinários, a filiação divina única de Jesus, um varão, o conceito de masculinidade presente nas três pessoas da Trindade Divina, a ideia da virgindade de Maria de Nazaré e várias outras ideologias sexistas. ${ }^{5}$

O presente artigo tem a finalidade de analisar os fatores que contribuíram para a emergência da Teologia Feminista, na América Latina, e o contexto dessa produção, bem como as estratégias e a contribuição da Teologia Feminista, no campo teológico latino-americano, para a promoção do diálogo inter-religioso, promovendo uma teologia da integridade, da paz e da dialogicidade. A partir dessas reflexões, hão de se discutir questões como: de que forma a mulher tem voz na Vida Religiosa? Qual sua relevância na criação de uma religião mais ecumênica e mais dialogal? Como a teologia feminista pode contribuir para o diálogo inter-religioso entre as mulheres e com as igrejas? Perguntas que não serão respondidas uma a uma, mas que indicam complexidades que seguiremos a refletir. E, ainda nessa introdução advertimos que vamos nos ater à Teologia Feminista na América Latina, mesmo sabendo das ricas possibilidades em se pensar também sobre a crítica

\footnotetext{
${ }^{4}$ AQUINO, M. P., A Teologia, a Igreja e a Mulher na América Latina, p. 9.

5 TOMITA, L., A Teologia feminista libertadora, p. 3.
} 
descolonial/decolonial produzida junto com o feminismo latino-americano, que não será tema nesse artigo. ${ }^{6}$

\section{O Contexto histórico e religioso das mulheres latino-americanas e o surgimento da teologia feminista latino-americana}

A América Latina é formada por vários países que passaram por um processo lento e longo de dominação e exploração colonialistas, da parte dos portugueses, espanhóis, franceses e holandeses. A exploração das riquezas nativas e da mão-de-obra escrava gerou dependência das colônias em relação à Europa. Com o passar do tempo, grande parte da cultura indígena foi dizimada pelos brancos e a abolição da escravidão não deu condições aos negros de terem uma vida livre e digna, pois continuaram sendo explorados e mal pagos, e assim, visando apenas gerar riqueza para outros. A situação das mulheres continuou sendo a de ocupar lugar subalterno, em virtude da continuidade de relações de poder patriarcal, seja no âmbito familiar, na esfera de trabalho e na educação. ${ }^{7}$

Segundo Maria Pilar Aquino, o europeu não somente "descobriu" nosso Continente como também "en-cobriu" ${ }^{8}$ povos, religiões e culturas inteiras. Na

${ }^{6}$ Maria Lugones nos adverte sobre o feminismo que dialoga a partir dos debates de Anibal Quijano e Walter Mignolo. LUGONES, M., Rumo a um feminismo descolonial. Assim como Edla Eggert analisa nos movimentos da decolonialidade como um modo de romper com a cópia que vinha sendo realizada na Teologia e na Educação e, outro modo de se fazer teologia por meio da Teologia da Libertação e da Educação Popular se produziu (EGGERT, E., Pesquisa em educação, movimentos sociais e colonialidade).

7 O processo de colonização no continente latino-americano foi marcado desde cedo pela exploração de riquezas naturais e de mão de obra barata. A maioria dessas atuais nações serviu às suas metrópoles e teve suas economias voltadas à exportação, o que impediu a constituição de um mercado interno consolidado, causando prejuízos e um grande atraso socioeconômico que permanecem até hoje. Outra característica histórica que é comum aos países da América Latina é a concentração de terras nas mãos da elite, mesmo após a descolonização. Esse fator é um dos responsáveis pelas marcantes desigualdades sociais e econômicas presentes nesses países. A história da formação da sociedade nacional latino-americana é a história de uma longa luta pela terra e de profundas marcas de opressão promovidas das mais diversas formas: colonização, bandeirismo, busca do ouro, coleta de especiarias, escambo com os nativos, escravização do índio e do negro, economia primária exportadora, latifúndio, engenho, agroindústria, fábrica, etc. Esse passado não é distante. Os golpes do Paraguai, do Equador e agora no Brasil, a América Latina e o Caribe revelam que suas populações seguem sendo dizimados na sua dignidade. Além disso, agora outros "invasores", europeus e asiáticos, representados por empresas multinacionais legalmente constituídas e instaladas nos países da América Latina, retomam com voracidade a retirada dos recursos não renováveis que ainda são abundantes no continente e perpetuam esse ciclo de exploração e atraso nesses países. Autores como Jessé Souza revelam essa realidade (SOUZA, J., O que significa Bolsonaro no poder).

${ }^{8}$ AQUINO, M. P., A Teologia, a Igreja e a mulher na América Latina, p. 39.

$$
\text { PqTeo, Rio de Janeiro, v. 3, n. 5, p. 27-46, jan./jun. } 2020
$$


relação entre Igreja-Estado, o Cristianismo hierárquico e patriarcal obscureceu a visão de mundo e os interesses das mulheres indo-americanas, das negras e mestiças. Toda essa destruição, trazida pelo processo de conquista e colonização, levou à substituição dos sistemas econômicos, religiosos e comunitários, subtraindo aos povos e impondo sistemas autodeterminados, excluindo mulheres como agentes nas diversas áreas e processos. ${ }^{9}$

O modelo imposto pelos conquistadores europeus acabou submetendo o destino das mulheres à decisão da autoridade patriarcal, tanto na expressão social, como religiosa. $\mathrm{O}$ homem branco considerava o negro, o índio e quem nasceu dessas uniões em grande parte forçada, como inferiores e, no caso da mulher, sua subjetividade foi suprimida e prevalecia, ainda mais, a discriminação e a superioridade dos homens sobre elas. As sociedades mantiveram a ideia de que, por natureza, os homens são mais propensos a dirigir esferas intelectuais, políticas, públicas e econômicas. Já as mulheres foram feitas para dar à luz aos filhos dos homens e, para se sacrificarem a serviço dos demais. Um resultado disso foi o silêncio e a invisibilidade das mulheres, nas esferas públicas.

O clero católico contribuiu para a continuação desse sistema políticocolonial dominador ao sobrepor a cultura europeia, com suas crenças, símbolos e consensos cotidianos, sobre os povos nativos, além de reproduzir os códigos éticos, determinados pela cristandade patriarcal europeia. A análise histórica da descoberta dos novos povos, do Novo Mundo, por Portugal e Espanha, profundamente influenciados pela Cristandade ${ }^{10}$ medieval, sugere uma troca de valores, tradições e crenças dos povos conquistados.

Conforme Aquino, vale ressaltar que as mulheres participaram, em grande medida, na resistência diante do poder hierárquico e colonialista sob diversas formas. Com efeito, as atividades das mulheres frequentemente reformularam as fronteiras entre o privado e o público através de participações coletivas, em movimentos de rebeldia contra a situação colonial, em seus protestos no âmbito sócio-religioso, na continuidade do tecido comunitário nas práticas solidárias, nas memórias e na transmissão da sua cultura.

Simultaneamente reconhecemos resistências da parte dos povos que aqui já estavam, ou dos que foram arrastados para cá e que neles também as mulheres

\footnotetext{
${ }^{9}$ AQUINO, M. P., A Teologia, a Igreja e a mulher na América Latina, p. 40.

${ }^{10}$ A palavra Cristandade surge já em 313, quando o Imperador Constantino I, com o Edito de Milão, ordenou o fim das perseguições à Igreja a quem concede o direito de ser religião lícita. Em seguida o Imperador Teodósio fez do Cristianismo a Religião do Império. A Cristandade indica o complexo de uma sociedade civil quando esta se identifica jurídica e sociologicamente com a Igreja cristã e com seus esquemas.
} 
resistiram como Dandara, ${ }^{11}$ que segue no imaginário do movimento negro da resistência. Do mesmo modo, lembramos de Soror Inês de la Cruz, a monja mexicana que subverte as leis do silêncio e da invisibilidade feminina na produção teológica do século XVII. ${ }^{12}$

É importante salientar a autonomia que algumas mulheres adquiriram, na época colonial: algumas entravam em conventos para se libertar da tutela do pai ou do marido. Embora, a Vida Religiosa fosse influenciada pelo Clero, muitas religiosas atuavam em missões e conseguiam conquistar espaços de decisão, em escolas e hospitais. No caso das mulheres de setores populares, a Igreja Católica permitia-lhes um certo poder simbólico, nas comunidades.

Segundo Jaci Candiotto, nos primeiros grupos feministas latinoamericanos e nas mobilizações das mulheres, no final do século XIX e no início do século XX, elas ainda temiam expressar seus interesses femininos, no intuito de organizar uma luta comum e preparada diante do poder patriarcal. Seus protestos estavam mais associados aos interesses de classes e da etnia das quais faziam parte. A revolução sexual dos anos setenta, a ascendência ao mundo do trabalho e da educação formal, a legalização do divórcio em alguns países, a emancipação das mulheres, ajudaram na elaboração de alguns objetivos comuns nas suas reivindicações. ${ }^{13}$

A Teologia da Libertação buscou redescobrir uma teologia, oculta durante séculos, pela estrutura de cristandade e seu quadro intelectual. Comblin afirma que essa nova teologia rompeu com a Cristandade, com o sistema colonial e eclesiástico vigentes. ${ }^{14}$ Dessa forma, os/as pobres, em suas lutas por libertação, descobriram uma verdadeira Igreja, anunciada por Jesus como esperança ao povo, opondo-se às autoridades e as suas formas de opressão: “A Igreja é chamada a contribuir para a promoção humana e cristã da mulher, ajudando-a a sair das situações de marginalização em que se possa encontrar, capacitando-a para sua missão, na comunidade eclesial e no mundo". ${ }^{15}$

Elsa Tamez foi ousada e realizou, no final da década de 1980, uma série de entrevistas, e desafiou figuras proeminentes da Teologia da Libertação, como por exemplo, Gustavo Gutierrez a se posicionarem acerca do Movimento Feminista e da opressão das mulheres. ${ }^{16}$ Os teólogos identificaram o sexismo como uma forma secundária de opressão e julgavam que levantar esta temática

\footnotetext{
${ }^{11}$ ARRARES, J., As lendas de Dandara.

${ }^{12}$ PAZ, O., Soror Inés de la Cruz. As armadilhas da fé.

${ }^{13}$ CANDIOTTO, J. F. S., A teologia feminista e seus giros hermenêuticos, p. 97.

${ }^{14}$ COMBLIN, J., A teologia das religiões a partir da América Latina, p. 49.

${ }^{15}$ DP 849.

16 TAMEZ, E., Las mujeres toman la palabra.
} 
poderia causar divisão. Segundo a autora, a mulher é um sujeito coletivo feminino definível dentro do amplo sujeito coletivo: homens, mulheres, anciãos, crianças etc., grupos também incluídos em outros grupos, como indígenas e negros que têm uma causa comum e enfrentam outros grupos que têm outras causas. Mas esse sujeito feminino tem uma especificidade dentro do sujeito histórico a que pertence. E suas contribuições e lutas não podem ser separadas da causa que o amplo sujeito coletivo defende, nem identificadas ou confundidas com as abordagens do referido sujeito. ${ }^{17} \mathrm{O}$ embate das teólogas nessa década de oitenta nos parece ser importante rememorar, pois ao que tudo indica, pouco sabemos dessa história e por incrível que parece revivemos embates semelhantes, quiçá piorados nesse final de segunda década do século XXI.

A Teologia Feminista da Libertação também questionou e questiona um Cristianismo que prega a passividade, a autonegação e submissão para justificar o sofrimento. Por isso, seu ponto de partida não é somente a experiência de Deus, na experiência de opressão e na luta pela justiça, mas também a experiência de Deus na ação de criar relações de irmandade, como afirma Ana Maria Tepedino:

O ponto de partida de uma Teologia Feminista não seria somente a experiência de opressão, a experiência de Deus na luta pela justiça, senão também a práxis do carinho, quer dizer, criar relações fraternais que são as que deveriam existir entre homens e mulheres, entre anciãos, jovens e crianças, enfim, entre todas as pessoas. ${ }^{18}$

As experiências relacionadas ao cuidado da vida e as relações positivas também são referências para a Teologia Feminista, oferecendo novas possibilidades de interpretações e outros elementos críticos. A experiência humana do carinho e do desejo passa a ser visto também como experiência de Deus e como ponto de reflexão teológica, como bem nos lembra a teóloga Wanda Deifelt:

Entendemos que as teologias negra, feminista e indígena passam a ser os novos momentos, as novas faces da Teologia da Libertação. Em um primeiro momento, entendemos como Teologia da Mulher dar uma voz à mulher como agente e dizer: "Nós também somos sujeitos, somos

17 TAMEZ, E., La Mujer como Sujeto histórico em la Produccion Teológica Mujer Latinoamericana, Iglesia y Teologia, p. 106.

${ }^{18}$ TEPEDINO, A. M., Muyer y teologia, p. 61. 
partícipes, também fazemos Teologia". Em um segundo momento, afirmamos que nossa Teologia é Teologia Feminina, porque o que nós fazemos é uma alternativa viável do que seria o fazer teológico tradicional. Em outros lugares da América Latina, também surgiu este fazer feminino contraposto a uma teologia racional. Apareceu, assim, um fazer teologia com ternura, com compaixão. \{...\} também usamos o instrumental de classe, de etnia, de idade, categorias que constituem a própria existência humana. Reduzir a Teologia Feminista à questão de gênero é reduzir o seu escopo. ${ }^{19}$

$\mathrm{Na}$ trajetória histórica da Teologia Feminista latino-americana feita por mulheres, ressaltamos o Primeiro Encontro, realizado no ano de 1973, em Petrópolis, RJ, pela CRB. Seu objetivo foi salientar o papel da mulher na Igreja. Desse Encontro nasceu a organização "Mulheres para o diálogo" a fim de despertar a consciência e a escuta das mulheres e desenvolver a Teologia Feminista latino-americana. Começa então um pensamento da mulher sobre si própria e que vem sendo trabalhado, pouco a pouco, na Igreja. Diversos estudos são feitos sobre a realidade das mulheres, na América Latina, através de congressos, simpósios e reuniões. O Conselho Mundial de Igrejas (CMI) dá início ao projeto "Comissão de Mulheres e Homens na Igreja", no ano de 1978, e no ano seguinte, ocorre um Congresso em Tepeyac, no México, cujo documento fala da situação de presença e, ao mesmo tempo, de ausência da mulher na Igreja, especialmente no que se refere à orientação e direção da Instituição. Nos anos 1980, realizam-se importantes encontros sobre a reflexão teológica a partir da mulher pobre latino-americana, sobre sua história e colaboração na Igreja. Maria José Rosado Nunes, participou da Comissão de Mulheres nesses encontros latinoamericanos que depois foram partilhados em diversos espaços eclesiais como as Comunidades Eclesiais de Base (CEBs), integrando mais mulheres na elaboração teológica da constituição das CEBs. No ano de 1993, o nome "Teologia Feminista da Libertação" foi adotado na reunião regional da Associação Ecumênica de Teólogas/os do Terceiro Mundo (ASETT/EATWOT). Vai nascendo uma nova Teologia, uma nova espiritualidade com sensibilidade para as relações étnico-raciais e decidida a repensar a hermenêutica. Uma espiritualidade encarnada e encarnadora, que valoriza o corpo e a corporeidade, uma nova mística integradora e holística, com seus ritos e sua simbologia. Ela traz uma nova visão de mundo: o "ecofeminismo" confrontando com uma nova visão de mundo, de relações sociais e econômicas.

${ }^{19}$ DEIFELT, W., A teologia feminista e o Deus de muitos nomes, p. 112. 
O desenvolvimento dos grupos de mulheres e da temática feminista na América Latina das décadas de sessenta em diante, possuem uma singularidade com relação as outras partes do mundo, devido às ditaduras militares instaladas em praticamente todos os países. Desse modo, os feminismos produzidos em terras latino-americanas misturaram a luta por democracia junto com a luta por dignidade e respeito aos temas anunciados desde a bandeira "o privado é político". ${ }^{20}$

Mulheres se descobriram como autoras teológicas, e também como protagonistas de uma transformação social e cultural, na América Latina. Descobrir a atuação de tantas mulheres, seja através da Bíblia, nas comunidades e em suas igrejas, impulsiona a luta e a busca delas em ocupar seu espaço, avançando para novos desafios da nossa atualidade, entre eles, a contribuição e a reflexão da Teologia Feminista diante do pluralismo religioso, num Continente tão multicultural, de diferentes etnias, raças e religiosidades.

\section{A contribuição da teologia feminista latino-americana para o diálogo inter-religioso}

Diante dos desafios atuais e dos tantos "sinais dos tempos", a opção pelos pobres ocupa um lugar privilegiado para o diálogo entre as muitas religiões. Paul Knitter afirma: "A libertação econômica e política, e especialmente a libertação integral, é demasiado grande para uma só nação, cultura ou religião. Precisa-se de uma cooperação intercultural e inter-religiosa numa práxis libertadora, e uma partilha da visão técnica da libertação". ${ }^{21}$

O pluralismo religioso apresenta-se como um desafio, pois exige um novo paradigma que vem convocar a Teologia a rever e a aprofundar, de forma dinâmica e efetiva, a sua dimensão hermenêutica, isto é, um novo modo de fazer teologia numa realidade inter-religiosa.

Busca-se, na América Latina, em linhas gerais, colocar em comum os diversos aspectos sociais e teológicos a partir da realidade das comunidades afro-americanas e caribenhas emergentes, nas últimas décadas do século 20; analisar e aprofundar, à luz da reflexão teológica, os grandes desafios provenientes da realidade pastoral dos povos negros; aprofundar as exigências de uma "evangelização inculturada" indicadas

20 Joana Maria Pedro é uma das pesquisadoras mais proeminentes no esquadrinhamento da história das mulheres feministas da América Latina. E junto com Karina Janz Woitowicz, publicaram no dossier Gênero, feminismos e ditaduras um bom estudo que torna explícito essa característica do feminismo na América Latina. WOITOWICZ, K. J.; PEDRO, J. M., O Movimento Feminista durante a ditadura militar no Brasil e no Chile.

${ }^{21}$ KNITTER, P., Para uma teologia das religiões, p. 15. 
pelas igrejas; aprofundar a reflexão sobre as práticas ecumênicas a partir das culturas e religiões de origem africana; e como as teologias feministas e índias podem representar o espaço de encontro, de diálogo e de construção de novos referenciais e paradigmas teológicos. ${ }^{22}$

A Teologia Feminista é uma visão que dá forma a um método e a um conteúdo da produção teológica em geral e se distingue das produções masculinas, ensinadas em igrejas, sinagogas e seminários. A experiência religiosa, o discurso e a prática de uma mulher são bastante diferentes da experiência religiosa de um homem, pois ambos vivem em contextos diferentes. A contribuição que as teologias feministas vêm dando à produção teológica não está apenas nos questionamentos que têm feito às tradições que foram construídas, sem levar em conta a presença e a experiência das mulheres em suas religiões, mas principalmente nas novas construções, conceitos e práticas que essas provocam, nas reflexões e estudos da teologia. Por ser uma teologia plural, feita em comunidade e em diálogo com outras teologias e religiões, parte do mundo das/os oprimidas/os. Segundo Claudete de Araújo, uma das principais contribuições da Teologia feminista está no diálogo inter-religioso:

A descoberta de um mundo pluricultural e multi-religioso, que gosta da diversidade e que não tem pretensão de se fechar em uma única experiência religiosa. Esse mundo pluricultural está aberto ao diálogo religioso de uma forma diferente do que conhecemos nas bases das instituições religiosas: o diálogo se dá com a apropriação e a somatória das experiências religiosas que alimentam o cotidiano, caracterizando, assim um sincretismo que, quando crítico, não deve ser visto com negatividade, mas como criatividade dos povos e como algo positivo. Assim, a Teologia é sempre plural porque as experiências religiosas também o são. ${ }^{23}$

Ao adentrarmos em uma das muitas igrejas ou templos que se espraiam nesse Continente de religiosidade plural e forçadamente ecumênico e interreligioso, notamos de imediato a forte presença feminina. As mulheres vêm resgatando muitas histórias do divino, nas experiências que fazem, dotadas de pesquisas antropológicas e históricas. As mulheres compõem, de fato, a maioria da população de fiéis. "Em nome de Deus", tornam-se biblistas, freiras, obreiras, pastoras, bispas, mães-de-santo, políticas e, do trabalho de mulheres indígenas, partilham-se muitas sabedorias. Na sombra ou nos palcos e altares,

${ }^{22}$ RIBEIRO, C. O., A Teologia Latino-americana diante do Pluralismo Religioso, p. 1452.

${ }^{23}$ ARAÚJO, C. R., Desafios e perspectivas à produção teológica a partir da contribuição das teologias feministas, p. 241-242. 
grande parte das fiéis carrega para a igreja o marido, os filhos, a família, o círculo social e profissional onde atuam. Contudo, sua presença continua silenciosa e suas razões não ditas.

Se o Cristianismo proclama um Deus de Amor que liberta as pessoas para novas possibilidades e para o discipulado, então, nós devemos aprender a falar sobre este Deus em termos não patriarcais e sexistas. A linguagem que se refere a Deus, se enraizada numa fé viva e numa comunidade viva, pode e deve mudar. O culto a Maria, na Igreja Católica, oferece-nos uma tradição e uma linguagem teológica que fala da realidade divina, em termos femininos e simbólicos. Esta tradição abrange os mitos e os símbolos das religiões de Deusas e demonstra que a linguagem feminina e seus símbolos possuem uma transparência em relação a Deus. Apenas se os cristãos derem a Deus nomes com imagens e termos femininos e masculinos é que a linguagem sobre Deus se tornará verdadeiramente "analógica" e não mais idolatrará o homem. ${ }^{24}$

A Teologia Feminista Latino-Americana é uma teologia comprometida com a vida e a luta das mulheres. Faz uma crítica às teologias que legitimam de alguma forma a discriminação e subordinação das mulheres nas Igrejas, religiões e sociedades. Relê a Bíblia, as linguagens e as diferentes tradições religiosas a partir da realidade de sofrimento e das perguntas, levantadas pelas mulheres no contexto em que vivem. Já afirmava Weiler: "A dignidade humana original, tanto da mulher como do homem, é 'terra sagrada'. É preciso 'tirar as sandálias' do preconceito, do pensamento pronto, das generalizações, para entrar no diálogo do diferente, da alteridade do face a face". ${ }^{25}$

A partir da conscientização de se perceber sujeito/grupo histórico oprimido, e também participante de uma comunidade de fé, a mulher exercita voz própria para nomear e transmitir sua experiência de fé. Como nos diz Ana Maria Tepedino: "é a própria tomada de consciência desta injustiça, que as leva a romper as barreiras que lhe são impostas, a enfrentar com coragem as dificuldades para ter voz e vez". ${ }^{26}$ Se a expressão Teologia Feminista sempre esteve embebida de termos contestatórios e reinvindicatórios nos países e centros de fé, é porque a palavra "feminismo" foi geralmente interpretada como uma categoria unitária. Porém, as teólogas latino-americanas enfatizam a produção de teologia no "feminino plural", ${ }^{27}$ isto é, suas experiências de vida,

${ }^{24}$ FIORENZA, E. S., Discipulado de Iguais, p. 109.

${ }^{25}$ WEILER, L., Chaves Hermenêuticas para uma releitura da Bíblia em perspectiva feminista, p. 226.

${ }^{26}$ TEPEDINO, A. M., BRANDÃO, M. L. R., A Força Mutante das Mulheres, p. 9.

${ }^{27}$ CAVALCANTI, T. M., Produzindo teologia no feminino plural, p. 359-370 
suas visões de mundo, de pessoa e de Deus vêm iluminadas por uma retomada e releitura do feminino na Bíblia e se constituem aspectos essenciais da teologia na ótica das mulheres da América Latina.

Para a teologia feminista os caminhos das relações são igualmente equivalentes e justos, não apenas na linguagem, mas a forma de pensar, fazer e conviver se tornam questões fundamentais nessa variedade de expressões e produções teológicas que são diversificadas, mas não se reduzem a um sistema rígido e acabado como muitas vezes a teologia propõe.

Portanto, o diálogo inter-religioso já é assumido e vivido pelas mulheres, especialmente por aquelas que fazem uma reflexão com base em orientação feminista. Ivone Gebara afirma que as mulheres latino-americanas têm vivido um processo diferente, original e bastante rico, mas a Teologia Feminista na América Latina mal começou a engatinhar. As teólogas em sua maioria trabalham com mediações produzidas por homens e ainda não ousam criticar essas mediações a partir de uma postura feminina, para não perder o espaço conquistado. ${ }^{28}$

$\mathrm{Na}$ ótica da Teologia Feminista, o diálogo inter-religioso é primordial para a criação de novas relações humanas porque precisa questionar o passado e o presente das igrejas patriarcais, promovendo a paz entre as religiões, a comunhão e a participação feminina na construção de uma teologia de libertação para todos. Porém, esse processo ainda carece de divulgação no mundo acadêmico teológico.

O diálogo inter-religioso é normalmente conduzido por homens e pelos homens. Percebemos isso nas imagens dos encontros onde quem lidera são os homens, líderes religiosos, com suas vestes litúrgicas, propagando solidariedade e respeito às diferentes crenças. Eles ainda protagonizam esse importante espaço de decisões. Isso também acontece no mundo acadêmico e teológico: as grandes publicações, volumes, artigos são predominantemente masculinos. A liderança na maioria das religiões continua sendo masculina, portanto, é esperado que as mulheres estejam ausentes ou sub-representadas nos oficiais diálogos interreligiosos. Embora a Religião seja, em grande parte, patriarcal (lideranças, rituais, teologias, tudo centralizado na figura masculina), são as mulheres que preservam a tradição no papel que "restou" para elas: no lar. Essa imagem de "mulher do lar" tem se tornado distante pela (tentativa) emancipação da mulher, porém, no campo religioso os avanços são mais difíceis.

Mesmo as mulheres, não sendo as grandes porta-vozes do diálogo interreligioso, no mundo "público", muitas mulheres empenham-se em promover, de diversas formas, o diálogo e a colaboração entre as religiões: criando grupos

${ }^{28}$ GEBARA, I., Mística e Política na experiência das mulheres, p. 920. 
de estudos ecumênicos de homens e mulheres, setores ecumênicos de juventude e espaços acadêmicos, compartilhando sua fé e luta diária e forjando novas perspectivas teológicas.

\section{Por uma teologia da integridade, da paz e da dialogicidade}

As frequentes dificuldades no diálogo inter-religioso indicam a necessidade de toda a sociedade entender melhor o papel da Teologia e o significado das religiões, num mundo tão multicultural e globalizado, com uma dimensão tão diversa da identidade humana. A tensão que se dá entre as religiões e crenças provém de ideologias seculares e de religiões agressivas, intolerantes e manipuladoras. Essas ideologias são usadas para legitimar o uso da violência, o machismo, a exclusão de minorias e a dominação política, social e de gênero. Torna-se cada vez mais importante o convívio entre as culturas, e a teologia é desafiada a promover vivências de integridade, de paz e de dialogicidade.

A Teologia Feminista surgiu como uma forma de as mulheres reagirem com eficácia à unilateralidade da Teologia dominante e à prática eclesial, que se apresenta como uma contribuição incompleta da Teologia já que exclui quase por completo as mulheres. O objetivo é claro: fazer existir uma Teologia da integridade, em que os gêneros coexistem e se completam. Segundo Tomita, o diálogo interreligioso promove relações de igualdade e valorização das diferenças:

O que se busca são elementos, princípios, práticas que sejam libertadoras não apenas para mulheres, mas também para os grupos marginalizados, os povos discriminados, as religiões e culturas desconsideradas. Tudo isto tendo como base um conceito de divindade não sexista, não patriarcal, não elitista, não racista. Além disso, apontam para a necessidade de que a Cristologia deve se transformar numa mensagem crística, não mais centrada num único indivíduo, mas nas relações igualitárias dentro de uma comunidade. Isto significa uma interrelacionalidade entre as pessoas, de poder partilhado e mais igualitário não só entre homens e mulheres, mas também tendo em vista um grande respeito aos velhos e às crianças e à toda a natureza. ${ }^{29}$

A espiritualidade ecumênica requer visão dialógica, profunda sensibilidade com as pessoas, as culturas e as questões que afetam a vida e a promoção da paz. Os povos da América Latina lutaram duramente para

${ }^{29}$ TOMITA, L., A contribuição da Teologia Feminista da Libertação para o debate do Pluralismo Religioso, p. 114. 
construir a paz com justiça e estabelecer regimes democráticos. Sabemos que há uma relação entre violência e religião, herdado de longas tradições culturais e religiosas e que ainda marca, de alguma forma, os tempos atuais. Contudo, há uma série de elementos dentro das próprias dinâmicas e conceituações religiosas que são geradores da paz. E daí surgem diversas formas, desafios e possibilidades. Um dos mais fecundos é o da "escuta"; saber ouvir o diferente e conhecer sua identidade. Trata-se, segundo Maria Clara Bingemer, de nos submetermos "à verdade onde quer que ela se encontre, aceitando o pluralismo de perspectivas e de nomes, quaisquer que eles sejam e onde quer que pulse o coração da vida. Esta missão é 'sair' da violência mimética e redutora da alteridade do outro e entrar numa dinâmica de paz polifacética e plural" ${ }^{30}$

Os esforços que valorizam a capacidade de diálogo e de sensibilidade ecumênica e aqueles que destacam a importância pública das religiões requer e possibilita uma compreensão mais apurada da realidade, um aperfeiçoamento de visões dialógicas e o cultivo de maior sensibilidade para a valorização da vida, em especial a dos pobres, e para a promoção da paz e da justiça. A integração da espiritualidade deve dar-se igualmente no tocante às situações que envolvem a vida humana, tais como os olhares masculino e feminino, e homo e heterossexuais. Da mesma forma, o diálogo inter-religioso deve contemplar as formas de serviço e compaixão com o sofrimento humano e as ações e manifestações públicas de protesto e contestação da injustiça social. A Teologia Feminista propõe, dessa forma, que se verifique no interior de cada tradição as exclusões que foram se reproduzindo e, em particular, a exclusão e a opressão das mulheres que geram as mais diversas formas de violência, entre elas, a intolerância, o proselitismo, o racismo e o sexismo.

A dialogicidade, defendida por Paulo Freire, refere-se à capacidade de ação e reflexão. É uma característica e uma qualidade de quem é dialógico e busca uma interação comunicativa na relação com o/a outro/a. Não há palavra que não seja práxis, ou que não surja da práxis, quando pronunciamos a palavra, estamos pronunciando e transformando o mundo. Na dialogicidade estão sempre presentes as dimensões do agir e do pensar. Ao pronunciar o mundo, segundo Freire, mostramos que humanamente existimos, se existimos, agimos e modificamos o mundo dado. Quando não há verdadeiro diálogo, não há encontro, amorosidade e respeito. Podemos sintetizar tudo isso expondo que o diálogo é este encontro das pessoas, imediatizadas pelo mundo, para pronunciálo, não se esgotando, portanto, na relação eu-tu. ${ }^{31}$

${ }^{30}$ BINGEMER, M. C. L.; COSTA, R. F.; RIBEIRO, M. H. S., Violência e não-violência no Novo Testamento, p. 288.

${ }^{31}$ FREIRE, P., Pedagogia do Oprimido, p. 91. 
O diálogo é uma relação horizontal, portanto, é um caminho indispensável, não somente nas questões vitais para a nossa prática religiosa, mas em todos os sentidos do nosso ser. Reler Freire em seus argumentos sobre a importância do diálogo, reforça em nós a significação entre as experiências de inter-reliogiosidade produzida pelas mulheres na ação e muito poucas vezes sinalizada, expressada e teorizada. O diálogo inter-religioso não pode ser apenas um debate entre religiões hegemônicas, mas precisa também considerar aquelas julgadas "inferiores" como as religiões indígenas que aparentam ter uma ausência da divindade e as religiões africanas que, na sua forma antropomórfica, representam a divindade através de deuses e deusas. Dessa forma, além de afirmar as identidades religiosas, o diálogo inter-religioso produz no interior de cada expressão religiosa mudanças e identificação de desafios. No caso do Cristianismo, é significativo enfatizar a necessidade de crítica do papel que ele desempenhou nos processos de colonização e catequização dos povos, cuja marca de intolerância, violência e rejeição das outras religiões e culturas, consideradas como demoníacas, está fortemente presente até os dias de hoje. A teologia feminista pode contribuir com essa revisão do lugar da religião no projeto de libertação. ${ }^{32}$

Nos últimos dez anos, as mulheres vêm conquistando seus espaços e sua liderança nas religiões, ao mesmo tempo em que tomam consciência da necessidade de estabelecer relações mútuas que favoreçam a convivência harmoniosa. Há uma significativa produção teológica publicada por teólogas, estabelecendo uma ponte para que seja possível caminhos de encontros e diálogo. Num clima de unidade/integração, elas buscaram uma interação com outras religiões, envolvendo lideranças, leigos, sacerdotes, bispos, chefes das Igrejas Cristãs, pastores, e outras pessoas que colaboram para o fortalecimento de suas comunidades. O principal trabalho destas mulheres seria diminuir as distâncias entre as Igrejas e religiões, procurando caminhos pacíficos no convívio com as diferenças, promovendo o debate em torno das questões femininas, da sexualidade. O encontro com a outra cultura, outra religião ou até outra maneira de viver a religião, enfim toda a comunidade que partilha desta vivência.

\section{Conclusão}

Entendemos que, por meio da idenficação dos esforços que as mulheres têm feito no diálogo inter-religioso, também é possível perceber o quanto elas

\footnotetext{
${ }^{32}$ RIBEIRO, C. O., A Teologia Latino-americana diante do Pluralismo Religioso, p. 1457-1458.
} 
experimentam a sua emancipação. Elas têm planejado e produzido encontros para uma sociedade mais fraterna, solidária, em que os povos e culturas se sintam reconhecidos. Pela promoção da plenitude da humanidade, enquanto mulheres, elas resgatam a singularidade do cuidado com a vida que vem, em boa medida, da experiência do feminino e, o espaço religioso, ganha uma nova força e voz nas estruturas patriarcais. E não apenas nas religiões monoteístas, mas também em todas que oferecem elementos de diversos patriarcalismos institucionalizados pelas religiões. A Teologia Feminista tem sido uma produção de conhecimento e um discurso global e inter-religioso que nos parece servir como ponte nas relações entre mulheres de diversas religiões, pois nenhuma mulher é plenamente livre enquanto outras mulheres não forem livres.

Nas práticas da Teologia Feminista Latino-Americana se confirma a opção pelos pobres e o seu engajamento pela libertação das mulheres, criticando o androcentrismo nas concepções religiosas e nas instituições, a partir da hermenêutica crítica dos textos e tradições sagradas, integrando as dimensões da cultura e da realidade humana em sua constituição seja nos aspectos celebrativo, comunitário, ecumênico, ético, lúdico e intuitivo, estético, pedagógico. Não é uma teologia só para mulheres, mas de todas gentes que transformam seu pensamento e ação pelo caminho da alteridade, no sonho de uma nova sociedade sem opressores(as), oprimidos(as) e sem excluídos(as).

Apesar de todo trabalho e produção desenvolvidos, a produção teológica feminista continua a ser pouco aceita nos espaços institucionais dominados pelos distintos cleros religiosos e por pessoas convencidas da superioridade da imagem patriarcal de Deus. Uma das batalhas atuais importantes das teólogas feministas, na América Latina, nomeadamente no Brasil, é em relação ao poder religioso que domina os corpos femininos. Elas continuam a lutar pela dignidade feminina, pois só assim será possível uma mudança no paradigma na forma como a História da Religião é contada. É necessário insistir na desmistificação de certos conceitos religiosos e questões associadas às condições aprendidas na forma como as relações de gênero são ensinadas e apreendidas, à salvação e ao monoteísmo. A opressão das religiões é algo a ser criticado e transformado através de questionamentos da linguagem conceitual masculina redutora, para que seja possível nomear quem é inominável e o "princípio fundante" numa perspectiva expressa de forma múltipla, plural, infinita.

\section{Referências bibliográficas}

AQUINO, M. P. A teologia, a Igreja e a Mulher na América Latina. São Paulo: Paulinas, 1997. 
ARAÚJO, C. R. Desafios e perspectivas à produção teológica a partir da contribuição das teologias feministas. In: SUSIN, L. C. (Org). Sarça Ardente: Teologia na América Latina: prospectivas. São Paulo: Paulinas, 2000. p. 238-248.

ARRARES, J. As lendas de Dandara. São Paulo: Cultura, 2016.

BINGEMER, M. C. L.; COSTA, R. F.; RIBEIRO, M. H. S. Violência e nãoviolência no Novo Testamento. In: BINGEMER, M. C. L. (Org.). Violência e Religião: Cristianismo, Islamismo, Judaísmo - três religiões em confronto e diálogo. São Paulo: Loyola / PUC-Rio, 2001. p. 67-113.

CANDIOTTO, J. F. S. A teologia feminista e seus giros hermenêuticos: reinterpretações de Deus, do ser humano e da criação. Rio de Janeiro, 2012. 297p. Tese. Faculdade de Teologia, Pontifícia Universidade Católica do Rio de Janeiro.

CAVALCANTI, T. M. Produzindo teologia no feminino plural. A propósito do III Encontro Nacional de Teologia na perspectiva da Mulher. Perspectiva Teológica, v. 20, n. 52, p. 359-370, set./dez. 1988. Disponível em: $<$ http://faje.edu.br/periodicos/index.php/perspectiva/article/view/1672/2000>. Acesso em: 03 jun. 2020.

COMBLIN, J. A teologia das religiões a partir da América Latina. In: TOMITA, L.; BARROS, M.; VIGIL, J. M. (Orgs.). Pluralismo e Libertação: por uma Teologia Latino-Americana Pluralista a partir da Fé Cristã. São Paulo: Loyola, 2005. p. 47-70.

DEIFELT, W. A teologia feminista e o Deus de muitos nomes. Cadernos IHU em formação, v. 2, n. 8, p. 111-113, 2006.

EGGERT, E. Pesquisa em educação, movimentos sociais e colonialidade: continuando um debate. Educação e Pesquisa, v. 42, n. 1, p. 15-26, jan./mar. 2016. Disponível em: $<$ http://www.scielo.br/scielo.php?script=sci arttext\&pid=S151797022016000100015\&lng-pt\&nrm=iso $>$. Acesso em: $0 \overline{3}$ jun. 2020. DOI: http://dx.doi.org/10.1590/S1517-9702201603135470

FIORENZA, E. S. Discipulado de Iguais: uma ekklesia-logia feminista crítica da Libertação. Petrópolis: Vozes, 1995.

FREIRE, P. Educação como prática da liberdade. Rio de Janeiro: Paz e Terra, 2007.

FREIRE, P. Pedagogia do Oprimido. Rio de Janeiro: Paz e terra, 2005.

GEBARA, I. Mística e Política na experiência das mulheres. Revista Eclesiástica Brasileira, v. 49, n. 196, p. 913-926, 1989. 
HICK, J. A metáfora do Deus encarnado. Petrópolis: Vozes, 2000.

JOHNSON, E. Aquela que é: o mistério de Deus no trabalho teológico feminino. Petrópolis: Vozes, 1995.

KNITTER, P. Para uma teologia das religiões. In: ASETT (Org.). Pelos muitos caminhos de Deus: desafios do pluralismo religioso à Teologia da Libertação. Goiás: Rede, 2003. p. 13-44.

LUGONES, M. Rumo a um feminismo descolonial. Revista Estudos Feministas, v. 22, n. 3, p. 935-952, set. 2014. Disponível em: $<$ https://periodicos.ufsc.br/index.php/ref/article/view/36755>. Acesso em: 03 jun. 2020. DOI: https://doi.org/10.1590/\%25x

PAZ, O. Soror Inés de la Cruz. As armadilhas da fé. Sao Paulo: Mandarin, 1998.

RIBEIRO, C. O. A Teologia Latino-americana diante do Pluralismo Religioso. Horizonte, v. 11, n. 32, p. 1436-1460, out./dez. 2013. Disponível em: $<$ http://periodicos.pucminas.br/index.php/horizonte/article/view/P.21755841.2013v11n32p1436>. Acesso em: 03 jun. 2020. DOI: https://doi.org/10.5752/P.2175-5841.2013v11n32p1436

SOUZA, J. O que significa Bolsonaro no poder. Jornal GGN, 08 mai. 2019. Disponível em: < https://www.brasildefato.com.br/2019/05/08/artigo-or-o-quesignifica-bolsonaro-no-poder-por-jesse-souza/>. Acesso em: 10 jun. 2019.

TAMEZ, E. La Mujer como Sujeto histórico em la Produccion Teológica Mujer Latinoamericana, Iglesia y Teologia. México: Editado pelo grupo Mujeres para el Dialogo, 1981.

TAMEZ, E. Las mujeres toman la palabra: en diálogo con teólogos de la liberación hablan sobre la mujer. San José: DEI, 1989.

TEPEDINO, A. M. Muyer y teologia. Apuntes para el quehacer teológico de la mujer en America Latina. In: AQUINO, M. P. (Org.). Aportes para uma Teologia desde la mujer. Madrid: Biblica y fe, 1988. p. 60-69.

TEPEDINO, A. M., BRANDÃO, M. L. R. A Força Mutante das Mulheres: paixão e compaixão. Teologia na Ótica da Mulher. Rio de Janeiro: Departamento de Teologia - PUC-Rio / Núcleo de Estudos sobre a Mulher, 1990.

TOMITA, L. A contribuição da Teologia Feminista da Libertação para o debate do Pluralismo Religioso. In: ASETT (Org). Pelos Muitos Caminhos de Deus: desafios do pluralismo religioso à Teologia da Libertação. Goiás: Rede, 2003. p. 108-119. 
TOMITA, L. A Teologia feminista libertadora: deslocamentos epistemológicos. In: FAZENDO GÊNERO, 9., 2010, Florianópolis. Diásporas, Diversidades, Deslocamentos. Anais... Florianópolis: Unidade Federal de Santa Catarina, 2010. p. 1-9. Disponível em: $<$ http://www.fg2010.wwc2017.eventos.dype.com.br/resources/anais/1278455 084_ARQUIVO_FAZENDOGENERO.final.pdf>. Acesso em: 09 jun. 2019.

WEILER, L. Chaves Hermenêuticas para uma releitura da Bíblia em perspectiva feminista. In: SUSIN, L. C. (Org.). Sarça Ardente: Teologia na América Latina: prospectivas. São Paulo: Paulinas, 2000. p. 222-238.

WOITOWICZ, K. J.; PEDRO, J. M. O Movimento Feminista durante a ditadura militar no Brasil e no Chile: conjugando as lutas pela democracia política com o direito ao corpo. Revista Espaço Cultural, v.10, n.21, p. 43-55, jul./dez. 2009. Disponível em: $\quad<$ http://e-revista.unioeste.br/index.php/espacoplural/article/view/3574/2833>. Acesso em: 04 de jun. 2020

\section{Edla Eggert}

Doutora em Teologia pela Faculdades EST

Docente na Escola de Humanidades da Pontifícia Universidade Católica do Rio Grande do Sul Porto Alegre / RS - Brasil E-mail: edla.eggert@pucrs.br

\section{Luísa de Lucas}

Mestranda em Teologia Pela Pontifícia Universidade Católica do Rio Grande do Sul Porto Alegre / RS - Brasil E-mail: marialuisa@notredame.org.br

Recebido em: 07/04/20

Aprovado em: 18/06/20 